\title{
a Cultura Negra e a poesia CUbana
}

\author{
Elena Godoy
}

\begin{abstract}
RESUMO
Este trabalho analisa as peculiaridades da trajetória cultural de Cuba no contexto dos paises da Hispano-América e suas correlaçōes com a poesia negra cubana.
\end{abstract}

Na parte continental da Hispano-América o poeta se volta às raças indigenas, assimila sua sensibilidade e expressa 0 sentimento de compenetração entre o indio e a paisagem. Não acontece assim nas Antiihas e sobretudo em Cuba, onde os indios desapareceram sem deixar vestígios. Aqui, a poesia de caráter folclórico tem que buscar a sua inspiração na cultura trazida da Africa, nos temas e motivos negros.

Quando os espanhois desembarcaram na ilha de Cuba em 1492, eles encontraram três tribos indígenas: guanahatabibes, siboneies e tainos. Pode-se falar da crueldade da colonização espanhola, mas acreditamos que os espanhóis não foram nem mais nem menos cruéis que os outros conquista. dores, no passado ou no presente. A tragédia dos índios cubanos durou pouco. Segundo a avaliação de Bartolomé de las Casas, antes do desembarque dos espanhóis em Cuba, em 1492 , viviam na ilha aproximadamente $300 \mathrm{mil}$ indios. $\mathrm{Em}$ 1517, quando Cuba, graças às conquistas de Diego Velásquez, passou a fazer parte da coroa espanhola, restavam $14 \mathrm{mil}$ indios; em 1537, 5 mil. O primeiro censo oficial de 1774 nāo traz dados sobre os indios. Conforme os dados estatisticos de 1965, existem em Cuba algumas dezenas de pessoas, em cujas veias há uma pequena porção de sangue indio.

O folclore cubano não herdou absolutamente nada das danças, cançōes ou rituais indios. Apenas as maracas indias foram assimiladas pelos escravos negros cubanos.

O escravo africano tornou-se a única mão-de-obra existente para trabalhos nas plantações de cana de açúcar e na 
produçāo de mantimentos. $\mathrm{E}$ provável que ainda Velásquez tenha trazido negros escravos em sua primeira expedição, em 1511; em 1532 já havia 500 negros escravos em Cuba. Calcula-se que por volta de 1606 viviam na ilha cerca de 20.000 escravos, estimando-se que no fim do século XVIII a populaçāo negra e mestiça seria de 40.000 . O censo de 1774 registrava uma populaçāo de 172.620 pessoas: 96.440 brancos e 76.180 negros e mestiços.

Caminho etnográfico semelhante percorreram também os outros paises do Caribe.

Nos paises com grande percentagem de população negra e mulata, desde os tempos remotos existiram (e ainda existem, embora seus limites ficam cada vez mais imprecisos) camadas heterogêneas de cultura popular: a hispano-crioula e a negra. A situação destas camadas, por força das condiçōes históricas e dos preconceitos raciais, sempre foi desigual. A "legalização" das tradiçōes negras, a volta dos artistas profissionais a estas camadas foi possivel somente no século $\mathrm{XX}$, numa situação de muaanças radicais na consciência da sociedade.

No século $\mathrm{XX}$ começaram a ser quebrados os limites nacionais, se acelerou a internacionalização da vida social e cultural, se alargaram os horizontes e fronteiras geográficas do "mundo de cultura", "mundo civilizado". Foram estabelecidos os contatos entre as culturas européias e as africanas, o que foi de importância essencial para a América Latina. Importante também foi aquele novo clima psicológico-social que começou a se criar no continente e no mundo inteiro. $O$ interesse pelas culturas africanas que se despertou naqueln época na Europa, "reabilitou" a arte negra americana na consciència dos artistas latino-americanos. Estas novas tendências européias obrigaram-nos a enxergar de uma maneira nova a realidade de seus paises, tomar uma nova consciência do que são as sua nações, do papel que desempenharam os negros na história de seus paises, e que riquezas para a arte guarda a cultura popular. Nesta situação nasce a poesia negra hispano-americana. A poesia negra, aparecendo como fenômeno "supranacional" no continente, em tais países como México, Costa Rica, Argentina e Uruguai como que se sobrepôs às linhas principais do processo literário sem mudá-lo. Ao mesmo tempo, nos países do Caribe, o negrismo veio a ser a expressão daqueles processos etno- e histórico-culturais que aconteciam aqui durante séculos. A influência sobre os artistas latino-americanos daquele interesse para a arte negra que se despertou na Europa no começo do século, foi enorme. Lembrando como foram criados os "Motivos de som", 
Nicolás Guillén observou que a moda da arte negra não chegou a Cuba da África mas foi trazida do Montparnasse e do Quartier Latin. Mas o próprio Guillén acrescenta que a moda européia para o africano se transformou nos países do Caribe num inodo de expressão de sua realidade. $\mathrm{Na}$ verdade. na Europa a volta dos escritores e poetas para o negro foi um mero episódio, porque foi a volta para um negro abstrato, construido conforme as tendências do desenvolvimento do pensamento estético. Na literatura antilhana esta volta não foi a volta para um negro abstrato e também não para o negro africano, mas para a própria realidade antilhana.

Como vimos, o primeiro contato do branco com o negro em Cuba foi a escravidāo. Os escravos entraram na ilha, apenas começada a colonizaçāo. Os cantos, as danças e os ritmos africanos constituiram sua única alegria dentro da mísera condição social. Os escravos transmitiram estas manifestaçōes típicas a seus descendentes em forma de cantos litúrgicos e rezas cheias de palavras mágicas que buscavam 0 apoio do ritmo. Já nestes cantos primitivos se sente a futura poesia afro-cubana. Mas quando o negro cubano canta algo fora dos ritos sacromágicos ,emprega o idioma castelhano e o faz ao estilo dos brancos. Nesta transculturaçāo, os negros esquecem seus velhos hinos tribais e se manifestam em cantos de comparsas, congas de rua e coplas politicas, mas os germes originários da África nunca desaparecem totalmente. Observa Guillén que “... um percurso de quatro séculos suscitou esse fenômeno que os sociólogos... designam com uma palavra que vem do inglês: transculturação. Deram os espanhóis de seu espirito - tāo complexo e matizado já, de sua língua, de sua cultura. Mas também deram os negros, e não deram menos, além de seu longo ofegar na plantação $\mathrm{e}$ no engenho, sob a escravidão sem piedade. Assim, a mestiçagem não é só a que resultou da união cômoda do amo com a escrava, a mestiçagem física... mas essa outra, profunda e longínqua, que vem de nossa dupla raiz fundamental. Por isso em Cuba é mestiço o branco, é mestiço o negro e é mestiço... o mestiço". E acrescenta: "Sem o negro nāo existiria Cuba como é hoje, Cuba com seu caráter e perfil, como também não existiria sem o branco..."

Em Cuba a questão da arte negra está unida aos mais complexos antecedentes, pois o negro sempre foi o fator essencial no processo de integração da nacionalidade cubana. Há séculos o negro desempenha o papel central na economia, na vida social e na cultura do país, e sua presença sente-se

1 Gulllen. Nicolás. Prosa de prisa. La: Villas. Ciniversidad Central de Las villas, 1962. D.181. 
desde os tempos remotos na literatura nacional. Podemos lembrar o primeiro poema cubano, El espejo de paciencia (1608), onde seu autor, Silvestre de Balboa, mostra os negros e os brancos lutando juntos, com a consciência do povo, contra o pirata francês Giron que ataca a ilha. Balboa clestaca a intervenção de um negro, assim como sua fala característica e pitoresca.

Ainda na época dos conquistadores espanhóis, os poetas cubanos pretendiam expressar os sentimentos dos escravos negros. Porém, como o negro era considerado como algo inconsciente, "baixo", "sujo", o africano e o mestiço trata. vam de se manifestar à maneira do branco, e o dominante era uma canção negra desnaturalizada pelas formas literárias brancas. Menos frequientes eram as manifestações folclóricas africanas que conservavam o caráter de "cantos de cabiīdo" (cabildos - associações clandestinas negras).

$\mathrm{Na}$ "alta" literatura o negro reapareceu por pouco tempo nos anos 30.40 do século passado, na criação dos românticos, os quais, voltando-se à realidade nacional, não podiam deixar de enxergar os negros. Nesta época surgiu até uma tendência de pôr o negro ou o mulato no centro de uma obra literária (cf. Cecilia Valdés, de Cirilo Villaverde). Mas este negro-herói vitima, sofrido logo desapareceu da literatura cubana, cedendo o lugar para outro protagonista da poesia romântica antiespanhola: o indio sibonei exterminado no começo da colonização (não podemos esquecer que nesta época o país entra em guerra contra a Espanha, lutando por sua independência). Para os poetas-siboneistas cubanos, 0 indio - a vítima dos colonizadores - veio a ser o símbolo do seu pais colonizado e rebelde. Mas ele era precisamente um símbolo, criado por intelectuais liberais, crioulos-separatistas. O negro, no pensamento dos escritores da Ilustração crioula, não entrava dentro do âmbito nacional. Para eles, o negro também era "o alienígeno", também tinha vindo, embora como escravo. Para um crioulo liberal da época o negro não podia ser o "material" para representar o ideal romântico. Era demasiada a diferença entre os princípios estéticos do romantismo e aquela imagem do negro que existia na concepção dos românticos, diferença esta ainda reforçada pelos preconceitos raciais. O objeto da estética romântica $e$, via de regra, distanciado da realidade no tempo ou no espaço e se encontra num mundo abstrato de um ideal absoluta e por isso possui qualidades especiais. Enquanto isso, o negro. escravo estava sempre "perto" com toda sua "feiura" da vida real. 
A mulatização da população cubana continuava intensa, as tradiçōes hispano-crioulas e negras se misturavam, penetrando nas camadas superiores da sociedade. Nos dias dos reis, negros, mulatos e até crioulos brancos participavam das procissōes carnavalescas - comparsas. Mas para a menta. lidade cotidiana o negro continuava sendo "o selvagem", e ainda o selvagem "feio", "horroroso". Enquanto isso, a figura do índio exterminado durante a conquista, no mundo antiIhano, estava encoberta pela neblina romântica.

Uma nova apreciação da imagem do negro surgia dentro da tradição popular-democrática que contrapunha ao clichê do sibonei idílico e ao clichê racista do "selvagem feio", um outro clichê: o clichê do "negro-cômico", "negro-simplāo". Este personagem cômico (variações: mulherengo, bravo, etc.) foi desenvolvido no teatro- bufo de Havana. As peças deste teatro estavam construidas sobre um triângulo amoro. so: o negro apaixonado pela linda mulata, a qual, por sua vez prefere o branco. O branco cantava décimas acompanhado por uma guitarra; o negro e a mulata dançavam guaracha, sacudindo o guiiro e as maracas (um fato curioso: a rumba ficou popular graças ao teatro-bufo, e algumas canções foram escritas especialmente para os espetáculos desse teatro, como E o caso da famosa "La cucaracha" - 1800). O racial nestas peças estava ligado ao social, ao nacional e ao libertador.

As máscaras do "negro feio" e "negro-simplão" começaram a cair nos anos da luta pela independência, quando, como disse J. Marti, deixou de existir a diferença entre o branco e o negro: a consciência democrática que nascia neste período, negava qualquer exploração racial, mas o insucesso do movimento libertador e a intervenção dos EUA retardaram seu avanço. Entretanto, a "legalizaçāo" da cultura, do princípio negro continuava vindo "de baixo", refletindo os processos da formação da camada afro-cubana da cultura popular. As palavras de Fernando Ortiz "sern o negro Cuba não seria Cuba" se transformaram num slogan dos artistas mais progressistas. A Revista de avance escrevia que os artistas deveriam interessar-se pela figura de Maceo (mulato, general na guerra da independência) em vez de deificar Atuei (cacique. sibonei).

No século $\mathrm{XX}$, como já observamos, chegou a Cuba (da Europa) a moda para a arte negra. Mas a própria situação interna do país - a ditadura de Machado (1925-1933), acompanhada pela acelerada "iankizaçāo" da ilha, - obrigou a muitos artistas a olhar com maior atençāo para os problemas do país. Os escritores e poetas cubanos descobrem as camadas sociais mais exploradas: os negros e os camponeses. 
Em 1928 Ramón Guirao e José Zacarias Tallet publicam seus "poemas-danças": Bailadora de rumba, o primeiro, e La rumba, o segundo. Os temas, a atmosfera e os ritmos desses poemas reproduzem os da velha rumba afro-cubana (que por sua vez remonta à dança erótica ritual africana). O negro de Guirao e de Tallet é exótico, mas é o negro cubano.

Também em 1928 Alejo Carpentier escreve o poema Liturgia de ñáñigo, abordando o outro tema tradicional da poesia negra: os rituais e as crenças dos africanos.

Entretanto, todos estes poetas apenas descreveram o mundo complexo da cultura negra. Em 1930 Nicolás Guillén, mulato, publica seu primeiro ciclo poético Motivos del son. Seus poemas opõem ao "negro primitivo" um "negro-gente", ao exótico - o real, às abstrações - o concreto da vida cubana.

Para Guillén, o tema negro sempre foi o centro e o ponto de partida de toda sua atividade criadora. Parte do negro, mas não se pode dizer que é apenas o cultivador do negrismo. Em toda sua obra predomina o desejo de criar uma poesia cubana autóctone, "a poesia mulata". Guillén viu a essência de Cuba na "mulatez", que não seria apenas uma confluência étnica do espanhol e do africano, mas toda uma uniāo cultural que originou um novo modo de vida depois de quatro séculos de convivência e que afetou a fala, a música, a poesia e o modo de viver dos cubanos.

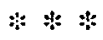

Elena Godoy, formada em Língua Espanhola pelo Instituto Pedagógico Hertzen de Leningrado (URSS), aluna de Mestrado em Lín. gua Portuguesa da UFPr, Professora do Curso de Extensão de Língua Russa da UFPr.

\section{SUMMARY}

This work analyses the peculiarities of the cultural development of Cuba in the Spanish.American context and their correlations with the cuban black poetry.

\section{REFERENCIA BIBLIOGRAFICA}

GUILlén, Nicolás. Prosa de prisa. Las Villas, Universidad Central de Las Villas, 1962. 